DOI 10.37882/2223-2982.2021.02-2.28

\title{
ГЕРМЕНЕВТИЧЕСКИЕ ПРИНЦИПЫ В ОБРАЗОВАТЕЛЬНОМ ПРОЦЕССЕ С ИСПОЛЬЗОВАНИЕМ АКТИВНЫХ МЕТОДОВ ОБУЧЕНИЯ АНГЛИЙСКОМУ ЯЗЫКУ
}

\section{HERMENEUTIC PRINCIPLES IN THE EDUCATIONAL PROCESS USING ACTIVE METHODS OF TEACHING ENGLISH}

Ya. Santsevich

Summary: The article deals with the model of formation of understanding and interpretation of texts in a foreign language in the learning process.

Keywords: hermeneutic circle, foreign language teaching, understanding, cooperation, search activity, creativity.
Санцевич Яна Сергеевна

К.полит.н., дочент, ПримИЖТ филиала ДВГУПС в г. Уссурийске santsevich_yana@mail.ru

Аннотация: В статье рассматривается модель формирования понимания и интерпретации текстов на иностранном языке в процессе обучения.

Ключевые слова: герменевтический круг, обучение иностранному языку, понимание, сотрудничество, поисковая активность, творчество.
$\mathrm{O}$ сновной тенденцией в образовании является освоение новой социальной позиции студентами в процессе обучения, основанной на их познавательной активности, которую невозможно формировать без включения в учебный процесс активных методов обучения, имеющих поисковый, творческий характер. Добиться этой цели возможно только при профессиональной подготовке педагогов, способных обеспечить педагогическое сопровождение поисковой активности учащегося как основного мотиватора учебной деятельности. Вместе с тем, система педагогического образования слабо ориентирует будущих специалистов на овладение профессиональными умениями и навыками по использованию, например, герменевтического метода или технологии сотрудничества. В результате педагог не способен творчески применить на практике методики и технологии организации сложной коммуникации на занятиях по обучению иностранному языку. Однако именно герменевтические принципы в образовательном процессе с использованием технологии сотрудничества способствуют овладению студентами универсальными учебными действиями, такими, как умение участвовать в совместной деятельности, умение группами, а не только индивидуально, работать с информацией.

Сам по себе анализ учебных текстов в едином учебном курсе настолько комплексный по своей структуре, что в нем очень трудно бывает иногда отделить восприятие от анализа, а наблюдения над конкретными фактами от обобщений. Все этапы изучения элементов учебного текста находятся во взаимодействии (взаимопроникновении, взаимодополнении) друг с другом, с другими темами курса, что и активизирует поисковую активность студента.
Задача преподавателя - не упускать заинтересованность учащихся в поиске таких взаимопроникновений, взаимозависимостей, где сам бы поиск осуществлялся в форме сотрудничества между учащимися, что, в свою очередь, стимулировало бы поисковую активность каждого из студентов. Решить эту проблему помогает «герменевтический круг», с помощью которого каким-то непостижимым, на непосвященный взгляд, образом обычный язык занятия превращается в материал для раздумий и обучения, где были бы предоставлены возможности для творческого поиска каждого участника образовательного процесса. Преподаватель призван воспитать из студента квалифицированного читателя базисного учебника, способного дополнить основную информацию поиском дополнительных сведений, способствующих восприятию текста как живой жизненной ткани. Только так можно способствовать становлению личности, формированию её жизненных позиций, сознательному участию студента в образовательном процессе.

Герменевтический круг - это принцип понимания текста, основанный на диалектике части и целого. Данное понятие введено Ф. Шлейермахером, который писал " ...как целое понимается из отдельного, но и отдельное может быть понято только из целого, имеет такую важность для данного искусства и столь неоспоримо, что уже первые же операции невозможно проделать без применения его, да и огромное число герменевтических правил в большей или в меньшей степени основывается на нем...» [6]. Автор утверждает, что процесс понимания строится на повторном возвращении от целого к части и от частей к целому, благодаря чему углубляется понимание смысла части, подчиняя целое постоянному развитию. 
Об этом пишет и Г. Гадамер: «Понять нечто можно лишь благодаря заранее имеющимся относительно него предположениям, а не когда оно предстоит нам как чтото абсолютно загадочное. То обстоятельство, что антиципации могут оказаться источником ошибок в толковании и что предрассудки, способствующие пониманию, могут вести и к непониманию, лишь указание на конечность такого существа, как человек, и проявление этой его конечности. Неизбежное движение по кругу именно В том и состоит, что за попыткой прочесть и намерением понять нечто «вот тут написанное» «стоят» собственные наши глаза (и собственные наши мысли), коими мы это «вот» видим» [1]. Следовательно, по Г. Гадамеру, задача состоит не в том, как выйти из герменевтического круга, а в том, как в него «правильно» войти, чтобы формировалась целостность знания.

Именно через герменевтический круг можно формировать представление у студентов о многоплановости языковой коммуникации. Поэтому важно фокусировать внимание обучающихся на элементах образной системы в процессе постепенного «движения в тексте». Вовторых, необходимо избегать схематизма, отвлеченности, «анатомирования» текста. Анализ должен постоянно сопровождаться синтезом, и важно в каждый момент работы не ограничиваться логически-понятийными выводами, а оживлять конкретно-образные представления обучающихся иностранному языку. В-третьих, надо создавать условия для появления и сохранения добытых смыслов в процессе разбора того или иного материала.

И.Н. Лазарева считает, что в процессе обучения иностранному языку именно герменевтический круг через процесс толкования текста с включением в диалог новых смыслов посредством вопросов и ответов, направляющих мыслительную активность студентов, позволяет эффективно строить смысловую коммуникацию. Вопросы подбираются таким образом, чтобы ответить на них можно было лишь вернувшись к тексту, что обучает студентов навыкам критического мышления, заставляет более внимательно смотреть на то, что они читают. Например: «Почему автор выбрал именно такое словосочетание в этом предложении; помогает ли то или иное слово добавить смысл к прочитанному абзацу?» Автор отмечает, что «герменевтические вопросы помогут рассмотреть обучающимся иностранному языку слагаемые смысла любого текста: определить авторскую позицию в высказывании, выявить скрытые связи и идеи, отделить главное от второстепенного - и тем самым научат добиваться глубокого понимания теста». Назначение герменевтического метода - в освоении учащимися техники работы с вопросами высокого познавательного уровня (уточняющие, аналитические, обобщающие и др.) [5, с. 14].

В ДВФУ с этой целью создан электронный спецкурс «Close Reading, Open-ended Questions», цель которого - обучить вопросной методике при анализе текста, чтобы внимание студентов концентрировалось на тех компонентах, которые существенны для анализа текста и его понимания.

В правильно подобранных вопросах преподавателя и реализуется принцип Ф. Шлейермахера, поскольку процесс понимания текста строится на расширяющемся круге вопросов, позволяющих повторно возвращаться от целого к части и от частей к целому, что меняет и углубляет понимание смысла текста, который, несмотря на ту или иную степень сложности, всегда является целостным по своей общей идее.

Как пишет Г.И. Гриднева, «учащийся постепенно выстраивает свою собственную систему лингвистических представлений. Поэтому обучение языку не должно быть простой передачей знания. У обучающихся иностранному языку должно постепенно сформироваться соответствующее реальности представление о языковом явлении - концепте» [3]. Создание новых ментальных структур в процессе обучения иностранному языку у студентов может формироваться только через целенаправленно сформированную потребность в самовыражении в процессе сложной коммуникации, что невозможно без понимания смысла текста. Так, например, к определенному учебному тексту можно попросить учащихся составить его план, с просьбой использовать в плане новые термины, значение которых понятно из самого текса. После отведенного времени на составление плана преподаватель просит зачитать планы некоторых учащихся, далее проходит совместное (диалог между преподавателем и студентами) обсуждение и выбор наиболее удачного плана, который при записи на доске дорабатывается через обсуждение отдельных абзацев. Пункты плана лучше записать в виде тезисов. Преподаватель обращает внимание учащихся на процедуру анализа текста: расчленили - выбрали главную информацию - соединили в плане - получили целостную картинку. По содержанию этого учебного текста можно попросить студентов составить кластер, актуализирующий проблему, поднятую в тексте. Поскольку составление кластеров - сложная задача, преподаватель центральные элементы кластера записывает сам, затем с помощью «мозгового штурма» конкретизирует крайние элементы. Работа с кластером обеспечивает ряд преимуществ в работе учащихся над любым текстом: наглядность, схематичность, простота запоминания, обозначение причинно-следственных связей, создание цельного образа содержания текста.

Многоразовое хождение по кругу, заданному текстом, операции по сужению текста, затем расширению, и опять сужению с помощью специально подобранных преподавателем вопросов и заданий, и опять расширению обеспечивают целостное восприятие текста, упро- 
щение его запоминания, причем всегда остается подсказка в виде кластера (схемы).

Через герменевтические принципы (круг, диалог) можно достигать прогнозируемые результаты работы учащихся с текстом на основе формирования у них целевой установки - научиться находить смысл прочитанного.

Планируемые результаты:

- развитие умения оценочного восприятия различных явлений через текст (герменевтический круг);

- развитие ассоциативно-образного мышления учащихся;

- освоение языка текста через поиск средств, передающих его основное смысловое содержание (план, кластер, вопросы).

Г.И. Гриднева в своей статье не использует понятие герменевтического круга, заменяя его когнитивным подходом в обучении иностранным языкам, при котором языковая информация может быть усвоенной, лишь когда она проанализирована. А использовать языковую информацию студент научается при достижении некоторой автоматизированности во владении ею. «Овладение иностранным языком - пишет автор - идёт несколько иным путём, чем это происходит при овладении родным языком. Именно при изучении второго, не родного языка учащийся может сразу идти ... от понимания свойств и назначения целого к его структуре и её составляющим [3].

На наш взгляд и автоматизация использования языковой информации достигается многоразовым хождением по тексту и созданием подсказок в виде схем. Отсюда формирование лингвистического знания как продукта происходит в процессе сложной коммуникации внутри студенческого сообщества, организующим центром которого является подготовленный к конкретному занятию преподаватель, использующий педагогический технологии с целью освоения и доведения до необходимого автоматизма конкретного языкового знания. Однако, сам учащийся является активным участником познавательного процесса, поскольку не заучивает новую информацию, а сам формирует свое знание через диалог с учащимися и преподавателем. Г.И. Гриднева предлагает с помощью специальных вопросов формировать лексическую память посредством образования устойчивых ассоциативных связей слова с ситуацией, тематикой; через кодирование лексической информации разными способами, чтобы научить студентов выделять в структуре значения слова семы, связанные с культурой народа, и умело пользоваться таким видом лексики [3].

Х.Н. Глазков при применении герменевтического круга предлагает использовать «секционную» технологию, при которой учебная группа делится на подгруппы или секции, каждой из которой необходимо придумать задания, на основе предложенных текстов (вопросы по тексту, краткий план текста, перевод слов и словосочетаний), чтобы идущая вслед за ними группа выполнила их. Герменевтический круг на данном этапе работы с учебным материалом «организован согласно следующему алгоритму: предпонимание - постановка вопросов согласно движению по герменевтическому кругу: «часть» - «целое» - социализация - истолкование» [2, с. 12]. Далее следует презентация каждой секцией своей части текста и совместное всеми секциями обсуждение вывода по содержательной части текста. Автор считает, что именно данная технология и обеспечивает сложную языковую коммуникацию, усвоение информации через интерпретацию текста, без которой не может происходить успешное освоение иностранного языка.

Как утверждает А.Ф. Закирова, в герменевтическом круге «в качестве системообразующей модели заложена идея организации образовательного процесса на основе взаимодополнительности технологизации процесса освоения обобщенных способов работы с учебным текстом, предполагающей операционализацию и алгоритмизацию процедур извлечения и переработки информации с опорой на психолингвистические теории понимания текста, а также использование собственно герменевтических процедур для актуализации и развития у учащихся способов понимания ценностно-смыслового содержания текстов» [4, с.18].

Итак, герменевтический круг реализуются в познавательном цикле, развертывающемся по схеме: познавательная ситуация - эмпирическая область - объект - предмет - средства - результат, в каждом из которых происходят изменения в восприятии учебного текста студентами, в процессе чего у них формируется потребность к самостоятельным наблюдениям и к оценке прочитанного. Проблема как раз и заключается в формировании у педагогов знаний об организации познавательной деятельности в процессе обучения иностранному языку. Поэтому программа подготовки педагогических кадров обязана включать в себя и формирование готовности освоения преподавателями современных методов и технологий организации учебной деятельности.

\section{ЛИТЕРАТУРА}

1. Гадамер Г.Г. О круге понимания [Электронный ресурс] // Актуальность прекрасного. - М.: Искусство, 1991. - С. 72-91. - 
Режим доступа: http://www.studfiles.ru/preview/3538778/

2. Глазков Х.Н. Герменевтический подход в обучении пониманию прочитанного обучающихся общеобразовательных школ [Электронный ресурс] // Педагогика сегодня: проблемы и решения: материалы III Междунар. науч. конф. (г. Казань, март 2018 г.). - Казань: Молодой ученый, 2018. - С. 11-13. - Режим доступа: https://moluch.ru/conf/ped/archive/276/13795/

3. Гриднева Г.И. Когнитивный принцип обучения на уроках английского языка [Электронный ресурс]. - Режим доступа: https://multiurok.ru/files/ koghnitivnyi-printsip-obuchieniia-na-urokakh-anghl.html

4. Закирова А.Ф. Теория и научно-образовательная практика педагогической герменевтики // Инновационные проекты и программы в образовании. 2013. - № 3. - С. 15-24.

5. Лазарева И.Н. Герменевтический метод в обучении сложной коммуникации на занятиях по иностранному языку [Электронный ресурс] // Сибирский педагогический журнал. - 2016. - №3. - С. 13-16. - Режим доступа: https://cyberleninka.ru/article/n/germenevticheskiy-metod-v-obuchenii-slozhnoykommunikatsii-na-zanyatiyah-po-inostrannomu-yazyku

6. Шлейермахер Ф. Академические речи 1829 года [Электронный ресурс]. - М.: Наука, 1987. - 218 с. - Режим доступа: http://anthropology.ru/ru/text/ shleyermaher-fde/akademicheskie-rechi-1829-goda

(с) Санцевич Яна Сергеевна (santsevich_yana@mail.ru).

Журнал «Современная наука: актуальные проблемы теории и практики»

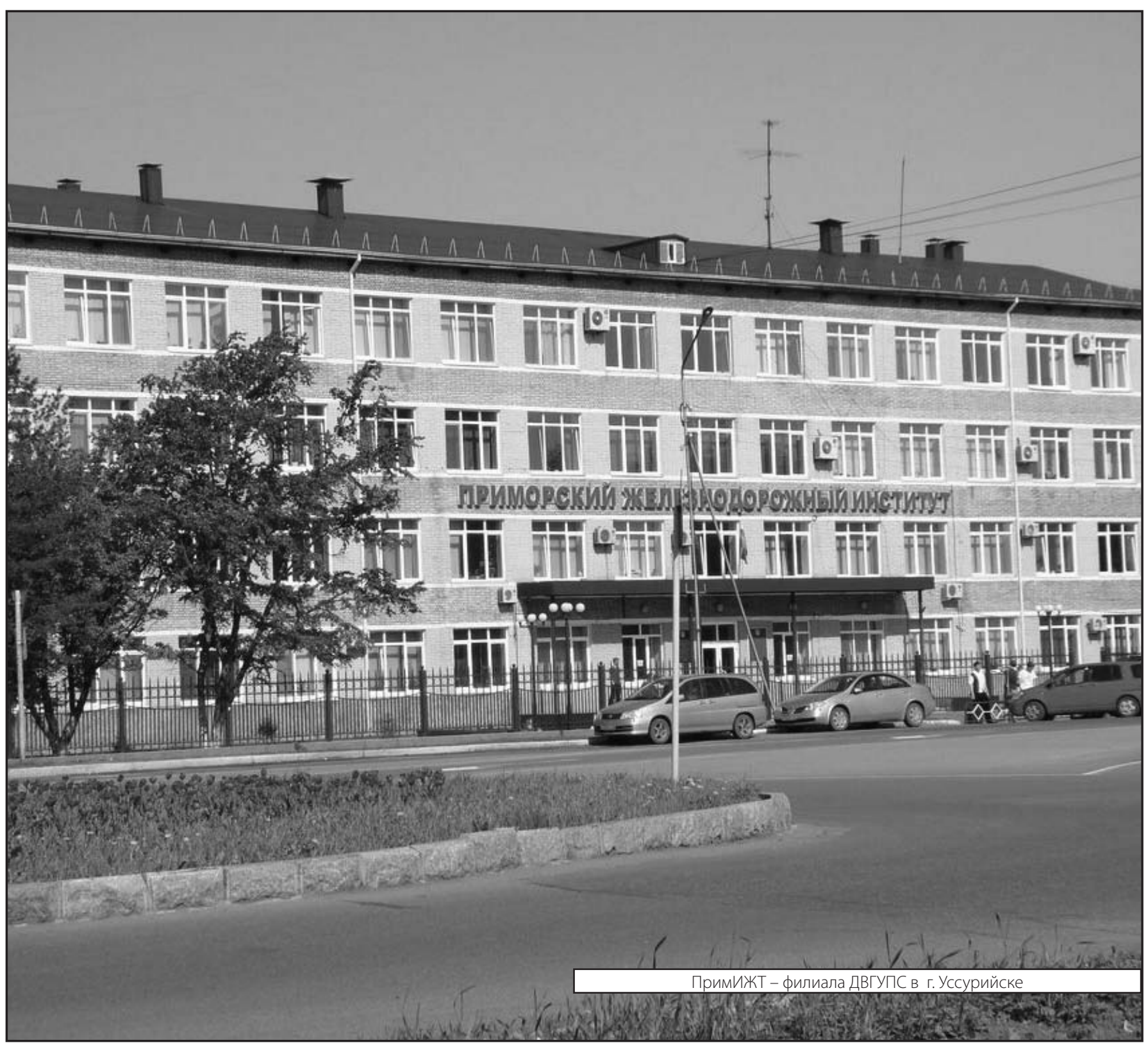

